\title{
Early warning intelligent system for road transportation risks
}

\author{
Robert Dobre, Laurențiu Ilie, Ionuț Săvulescu, Mădălina Teodor \\ Geomorphology - Pedology - Geomatics Department \\ Faculty of Geography, University of Bucharest \\ Bucharest, Romania
}

\begin{abstract}
This project is based on an action that is agreed with the Innovation and Networks Executive Agency (INEA) and is based on Intelligent Transport Systems. Romanian TEN-T network is seriously affected by natural risks such as landslides, torrential erosion, rock falls, avalanches, floods and heavy snow. These natural hazards lead to numerous road accidents which cause important casualties and material losses every year.
\end{abstract}

The overall objective of the action is to improve traffic safety and reduce congestion of the Romanian road Core and Comprehensive Network by putting in place a compatible, accessible and interoperable intelligent transportation system (ITS) that will provide traffic and travel information services in all European languages via web.

Keywords - intelligent transport; roads; geomorphological processes

\section{INTRODUCTION}

This project is based on an action that is agreed with the Innovation and Networks Executive Agency (INEA) Department C - Connecting Europe Facility (CEF). The action aim is to contribute to the implementation of the comprehensive network, horizontal priority: Telematic applications systems for road (ITS), and on the core network Corridors: Orient/East-Med, Rhine-Danube.

\section{LOCATION OF THE ACTION}

The project is representative for the country of Romania and is based on the TEN-T Core network corridors

\section{SCOPE AND OBJECTIVES}

The ITS (Intelligent Transport Systems) are being applied to facilitate mobility, make better use of existing infrastructure, improve safety and help mitigating negative environmental impacts. Deployment of ITS is also motivated by the increased difficulty of expanding transportation capacity through conventional infrastructure building.

Romanian TEN-T network is seriously affected by natural risks such as landslides [1], torrential erosion [2], rock falls [3], avalanches, floods and heavy snow [4]. These natural hazards lead to numerous road accidents which cause important casualties and material losses every year [5].

The overall objective of the action is to improve traffic safety and reduce congestion of the Romanian road Core and Comprehensive Network by putting in place a compatible, accessible and interoperable intelligent transportation system (ITS) that will provide traffic and travel information services in all European languages via web.

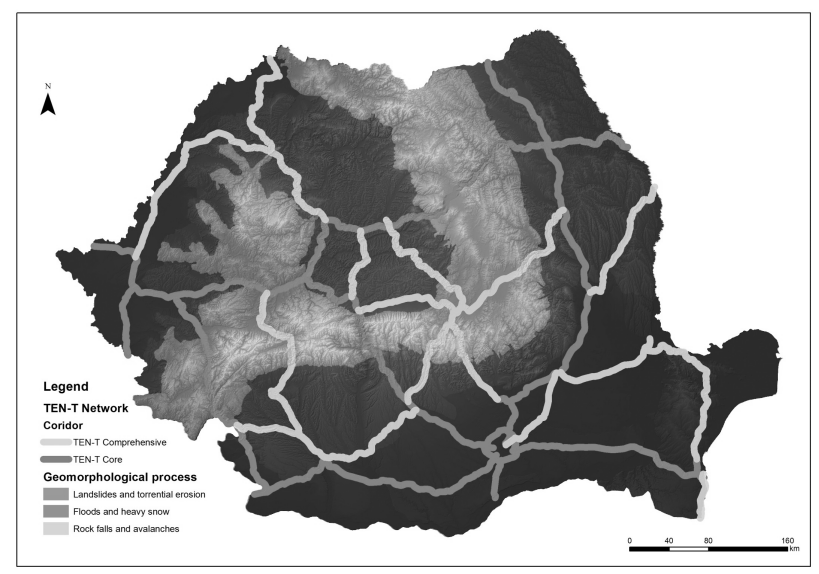

Fig. 1. The identification of the main general geomorphological processes that affect the TEN-T Core and Comprehensive network

To deliver on the overall objective of the Action, there are three specific objectives, which will be met by carrying out eleven activities within the Action:

1. Sizing risks that can affect road transportation;

2. Identification of the data sources;

3. Elaboration of the tender documentation and public tender process;

4. Back-end platform and applications architecture design;

5. Development of the back-end platform;

6. Developing the web application;

7. Developing the mobile applications;

8. Collecting user's feedback;

9. Improving applications on the basis of the collected feed-back;

10. Validation and testing;

11. Information and Advertising Campaign; 


\section{Project Management.}

The first specific objective is to contribute to the accessibility of interoperable accurate road and traffic saferelated data across the EU through the set-up of a national access point. This objective will be met by identifying and characterising the list of risks that can affect road transportation [1], through the identification of the corresponding data sources in line with and by making data available in a standardised format across Europe and in neighbouring countries through a national access point that will consist on an interoperable application module designed, set-up and made available via web and mobile [4].

The second specific objective is to contribute to reducing the number of accidents, transport time and fuel consumption in the Romanian TEN-T network by providing real-time safety-related traffic information services to road users via well-functioning web and mobile applications. These services will cover information on a wide range of risks and will be easily accessed by the general public using various devices, including smartphones, tablets and laptops. This objective will be met through the design and the implementation of a cloudbased back-end platform, a cloud-based web application and some mobile applications for the most popular Operating Systems which will provide real-time safetyrelated traffic information services to road users. A testing and validation process will be carried out so as to ensure that the web and mobile applications have been designed in compliance with the identified data sources and risks and implemented in line with the applications design. Moreover, the web and mobile applications will be finetuned on the basis of the user's feedback collected through dedicated forms as well as from the comments posted in the application stores. A software development firm will be contracted via a public procurement procedure for the design, the development and fine-tune of the back-end platform, the web and the mobile applications.

The third specific objective is to inform the road users, ITS service providers and road users about the results of this Action. This objective will be met by designing and implementing an Information and Advertising Campaign.

\section{USING THE RESULTS} study.

The results of this project can be determined by case

On December 1st 2015, on the DN7 national road (Olt Valley, Core Network) it was a minor accident (without casualties). The accident led to block traffic in both directions. The accident was caused by falling rocks which broke away from the slopes $\left(2200 \mathrm{~m}^{3}\right)$. In order to increase the road safety, the National Company of Motorways and National Roads in Romania (CNAIR). Thus, several hundreds of vehicles including dozens of cargo transport truck were blocked on the Olt Valley. After several hours of waiting and an assessment of CNADNR specialists, it was decided to redirect the traffic on an alternative route.

The case study was developed for a charged truck on the Nădlac (Romania - Hungary border) - port of Constanta on the Black Sea route. The analyzed vehicle has 40 tones mass, 5 axes, emmissions class Euro 5 and has green pollution permits.
Three scenarios were simulated:

A scenario - Transport by truck to a normal situation

$B$ scenario - the truck transport without the benefit of accident alert along its route (Scenario without the project) - present situation

C scenario - the truck transport with the benefit of alert along its route (project scenario) - results from CEF projects. Has been completed, the paper is ready for the template. Duplicate the template file by using the Save As command, and use the naming convention prescribed by your conference for the name of your paper. In this newly created file, highlight all of the contents and import your prepared text file. You are now ready to style your paper; use the scroll down window on the left of the MS Word Formatting toolbar.

\section{A scenario}

In a normal situation (without route incident), the truck route linking Nadlac to Constanta it is $834 \mathrm{~km}$ : Nădlac Arad - Timișoara - Lugoj - Deva - Sibiu - Rm. Vâlcea Pitești - București - Constanța.

TABLE I. THE PARAMETERS FOR A SCENARIO

\begin{tabular}{|c|c|c|c|c|c|c|c|c|}
\hline $\begin{array}{c}\text { Route } \\
\text { length } \\
(\mathrm{km})\end{array}$ & $\begin{array}{c}\text { Journey } \\
\text { time }\end{array}$ & $\begin{array}{c}\text { Fuel } \\
\text { consuption } \\
\text { (liters) }\end{array}$ & $\begin{array}{c}\text { Average } \\
\text { consumpt } \\
\text { ion } \\
\text { (liters) }\end{array}$ & $\begin{array}{c}\text { Total } \\
\text { Fuel } \\
\text { Cost } \\
(\text { euro })\end{array}$ & $\begin{array}{c}\text { CO2 } \\
(\mathrm{kg})\end{array}$ & $\begin{array}{c}\text { NOx } \\
(\mathrm{g})\end{array}$ & $\begin{array}{c}\mathrm{N2O} \\
(\mathrm{g})\end{array}$ & $\begin{array}{c}\mathrm{CH} 4 \\
(\mathrm{~g})\end{array}$ \\
\hline 834 & $15 \mathrm{~h} 38$ & 321 & 38,5 & 319,6 & 849 & 3352 & 49 & 1,92 \\
\hline
\end{tabular}

\section{B scenario}

In the event that an incident occurs on the truck route (Nadlac to Constanta Port), the route is rerouting after arriving at the incident and analyzing the situation. In this scenario, the route is: Nădlac - Arad - Timișoara Lugoj - Deva - Sibiu - Brezoi - incident location - Brezoi - Sibiu - Brașov - Predeal - Câmpina - Ploiești București - Cernavodă - Constanța. The route length has 979 km, 145 km 14 more than the A scenario.

TABLE II. THE PARAMETERS FOR B SCENARIO

\begin{tabular}{|c|c|c|c|c|c|c|c|c|}
\hline $\begin{array}{c}\text { Route } \\
\text { length } \\
(\mathrm{km})\end{array}$ & $\begin{array}{c}\text { Journey } \\
\text { time }\end{array}$ & $\begin{array}{c}\text { Fuel } \\
\text { consuption } \\
\text { (liters) }\end{array}$ & $\begin{array}{c}\text { Average } \\
\text { consumpt } \\
\text { ion } \\
\text { (liters) }\end{array}$ & $\begin{array}{c}\text { Total } \\
\text { Fuel } \\
\text { Cost } \\
(\text { euro })\end{array}$ & $\begin{array}{c}\text { CO2 } \\
(\mathrm{kg})\end{array}$ & $\begin{array}{c}\mathrm{NOx} \\
(\mathrm{g})\end{array}$ & $\begin{array}{c}\mathrm{N2O} \\
(\mathrm{g})\end{array}$ & $\begin{array}{c}\mathrm{CH} \\
(\mathrm{g})\end{array}$ \\
\hline 979 & $19 \mathrm{~h} 09$ & 387,7 & 39,6 & 386 & 1023 & 4050,6 & 57,6 & 2,27 \\
\hline
\end{tabular}

\section{C scenario}

In the chase that the truck driver is alerted by the application, the route is redirected before arriving at accident. Thus, the route will be as follows: Nădlac - Arad - Timișoara - Lugoj - Deva - Sibiu - Brașov - Predeal Câmpina - Ploiești - București - Cernavodă - Constanța. The route has $870 \mathrm{~km}$. In this case, it will be $109 \mathrm{~km}$ less then B Scenario and just $36 \mathrm{~km}$ more than A Scenario.

\section{CONCLUSIONS}

The project may represent a first step in a larger project that will aim to implement across borders in cooperation with the TEN-T networks roads, in neighboring countries (Hungary, Bulgaria and Serbia). 


\section{REFERENCES}

TABLE III. THE PARAMETERS FOR CSCENARIO

\begin{tabular}{|c|c|c|c|c|c|c|c|c|}
\hline $\begin{array}{c}\text { Route } \\
\text { length } \\
(\mathrm{km})\end{array}$ & 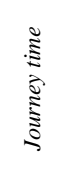 & 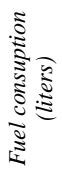 & $\begin{array}{c}\text { Average } \\
\text { consumpt } \\
\text { ion } \\
\text { (liters) }\end{array}$ & $\begin{array}{l}\text { Total } \\
\text { Fuel } \\
\text { Cost } \\
\text { (euro) }\end{array}$ & $\begin{array}{l}\mathrm{CO} 2 \\
(\mathrm{~kg})\end{array}$ & $\begin{array}{c}N O x \\
(g)\end{array}$ & $\begin{array}{c}N 2 O \\
(g)\end{array}$ & $\begin{array}{c}\mathrm{CH} 4 \\
(\mathrm{~g})\end{array}$ \\
\hline 870 & $\begin{array}{l}16 \mathrm{~h} \\
28\end{array}$ & 335 & 38,5 & 333,5 & 884 & 3522,7 & 51 & 2 \\
\hline
\end{tabular}

TABLE IV. DIFERENCE BETWEEN SCENARIO B AND SCENARIO C (PERCENT \%)

\begin{tabular}{|c|c|c|c|c|c|c|c|c|}
\hline $\begin{array}{c}\text { Route } \\
\text { length } \\
(\mathrm{km}\end{array}$ & 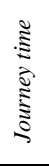 & 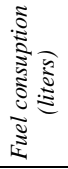 & $\begin{array}{c}\text { Average } \\
\text { consumpt } \\
\text { ion } \\
\text { (liters) }\end{array}$ & $\begin{array}{l}\text { Total } \\
\text { Fuel } \\
\text { Cost } \\
\text { (euro) }\end{array}$ & $\begin{array}{c}\mathrm{CO} 2 \\
(\mathrm{~kg})\end{array}$ & $\begin{array}{c}N O x \\
(g)\end{array}$ & $\begin{array}{c}N 2 O \\
(g)\end{array}$ & $\begin{array}{c}\mathrm{CH} 4 \\
(\mathrm{~g})\end{array}$ \\
\hline 11,1 & 14 & 13,6 & 2,8 & 13,6 & 13,6 & 13,0 & 11,5 & 11,9 \\
\hline
\end{tabular}

The results of the project has major environmental benefits in terms of air pollution, the risk of accidents, as well as benefits related to the transport costs.

In this first phase of implementation of the projected costs are higher because it will create a structure and database, the second phase having lower costs as it would target only the update of the created database

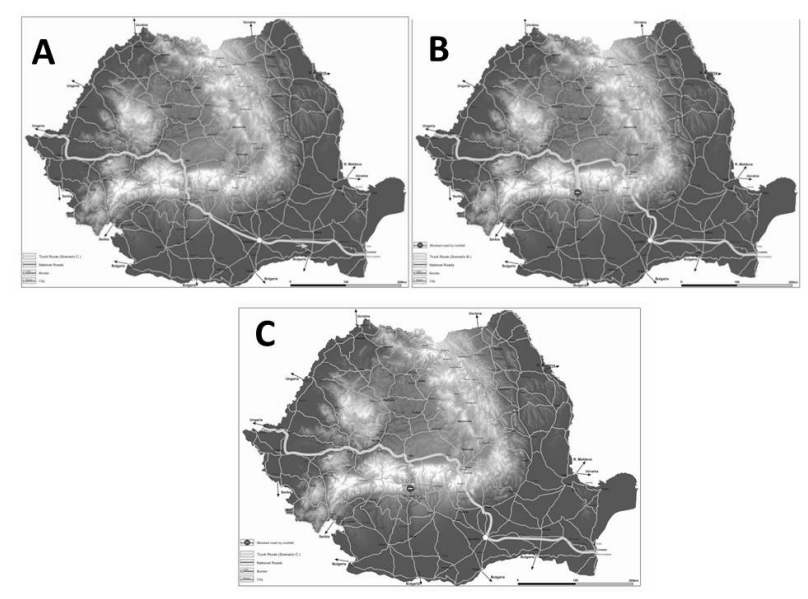

Fig. 2. Auto rote in a normal situation, truck transport without the benefit of accident alert along its route (Scenario without the project) and truck transport with the benefit of alert along its route (project scenario)

\section{ACKNOWLEDGMENT}

This project was financial supported by the European Commission - Innovation and Networks Executive Agency (INEA) Department C - Connecting Europe Facility (CEF), 2015-RO-TM-0435-W grant.
[1] R. Dobre, Relatia dinamica reliefului-infrastructura de transport, Editura Etnologică, București, 2016. (in Romanian)

[2] T. Mădălina, "Geomorphological processes susceptibility assessment using GIS analysis in Ilwis software. Case study: Ialomiţa Upper Valley (Romania)", Revista de Geomorfologie, vol. 15, pp. 109-118, 2013.

[3] R. Dobre, Pretabilitatea reliefului pentru căi de comunicaţii şi transporturi în Culoarul Prahovei (sectoarele montan şi subcarpatic), Editura Universitară, Bucureşti, ISBN 978-606-591235-9, 245 p., 2011. (in Romanian)

[4] F. Grecu, Hazarde şi riscuri naturale, Ed. a IV-a, Editura Universitară, Bucureşti, 2009. (in Romanian)

[5] R. Dobre, B. Mihai, and I. Săvulescu, "The Geomorphotechnical Map: a highly detailed geomorphic map for railroad infrastructure. A case study for the Prahova River Defile (Curvature Carpathians, Romania)”, Journal of Maps, v2011, pp. 126-137. 10.4113/jom.2011.1155, 2011 